\title{
Analysis of Quality in Brazilian E-Commerce (B2C)
}

\author{
Pedro Luiz de Oliveira Costa Neto ${ }^{1}$, José Paulo Alves Fusco ${ }^{1,4}$, \\ and João Gilberto Mendes dos Reis ${ }^{1,2,3}$ \\ ${ }^{1}$ Departament of Production Engineering, Paulista University \\ Dr. Bacelar 1212, 04026002 São Paulo, Brasil \\ ${ }^{2}$ College of Technology, Centro Estadual de Educação Tecnológica Paula Souza \\ Sonho Gaúcho 641, 03685000 São Paulo, Brasil \\ ${ }^{3}$ Departament of Production and Logistics, Camilo Castelo Branco University \\ Carolina Fonseca, 584, 08230030 São Paulo, Brasil \\ ${ }^{4}$ Departament of Production Engineering, São Paulo State University, \\ Engineer Luiz Edmundo Carrijo Coube 14-01, 17033360 São Paulo, Brasil \\ politeleia@uol.com.br,
jpafusco@uol.com.br,
betomendesreis@msn.com
}

\begin{abstract}
The business world has changed the way how people think and act on products and services. In this context, the most recent amendment of the scenarios of retail operations has been the use of technology in sales and distribution. The internet has revolutionized the way people communicate, and moreover as they purchase their goods and services. Thus, the e-commerce, specifically the relation business to customer, or simply $\mathrm{B} 2 \mathrm{C}$, has acted so convincingly in this change of paradigm, namely the purchases in the physical location for the virtual site. Quotes online, ease of payment, price, speed of delivery, have become real order winners of applications for companies that compete in this segment. With the focus on quality of services on e-commerce, the research examines the dimension related to the quality of services, and looks for what of these factors are winners of applications.
\end{abstract}

Keywords: Supply chain; business to customer; dimensions of quality; quality of services; order winners.

\section{Introduction}

The globalization process, seen in the late years, has led companies into a never ever seen or dreamt competition before, the introduction of new commercial ways, provides by information technology and communication (ITC) such, for example the advent of internet, has enabled companies with new ways to reach their clients, in this global environment, finding a great opportunity, due to growing necessity of saving time in operations. Thus, companies have started to use these technologies developed to reach their clients faster and with more practicality, which has made e-commerce possible as we know today. In this context, understanding which are consumers' expectations is crucial to the development of the whole Supply Chain. 
To this extent, this research lies on the width analysis of quality and also how it can contribute so that the enterprise can become more competitive in the attendance of consumers' expectations in the B2C segment keeping its procesing costs and reasonable delivery orders and also producing benefits to all stakeholders.

\section{Backgrounds}

\subsection{Supply Chain Management}

The Supply Chain (SC) can be defined as a net of independent companies or partially independent ones, which are effectively responsible for the acquisition, products and release of a certain product or service to the final costumer [1].

Analysing the general concept Supply Chain, we can amplify the idea by using the definitions of management of these processes. The Supply Chain Management (SCM) covers all the mentioned activities to the flow and merchandise transformation, from the extraction to the final consumer, as the flow of information [2]. The management of the SC is the integration of these activities through enhanced relationships in the Supply chain, having as a goal conquering sustainable competitive advantage [2].

Thus, managing effectively the SC is essential to reach sustainable competitive advantage, reduce the use of resources in the process of production and pricipally ensure the survival and profit of involved partners.

\subsection{E-Business}

The new information technology and communication have approached clients to enterprises and improved the access to information about accomplished transactions,

\begin{tabular}{|c|c|c|}
\hline & Company & Customer \\
\hline Company & $\begin{array}{l}\text { Relationship } \\
\text { - More common. Present throughout } \\
\text { the whole network except the last } \\
\text { point in the supply chain } \\
\text { Examples of e-commerce } \\
\text { - EDI Networks }\end{array}$ & $\begin{array}{l}\text { Relationship } \\
\text { - Retail Operations } \\
\text { - Catalogues Operations and others. } \\
\text { Examples of e-commerce } \\
\text { - Web Retail Store }\end{array}$ \\
\hline Customer & $\begin{array}{l}\text { C2B } \\
\text { Relationship } \\
\text { - Customer "offers", the company } \\
\text { answers } \\
\text { Examples of e-commerce } \\
\text { - Some Air Line Tickets Operators }\end{array}$ & $\begin{array}{l}\text { Relationship } \\
\text { - Auctions Relationships, "exchange" and } \\
\text { trading } \\
\text { Examples of e-commerce } \\
\text { - Collectors Web Sites }\end{array}$ \\
\hline
\end{tabular}

Fig. 1. Relationship Matrix between customer/company. Source: Adapted from [4]. 
which has made a real revolution. All this range of information and speed in processes have led consumers to demand only fast-delivered and reasonable-priced products whose quality fulfills or exceeds their expectations. Consumers are willing to pay for the price of a product once they believe they can get the sales value similiar or superior to their investments [3].

In this paradigm change, the e-commerce having the final consumer as a goal has become an important tool to accomplish not only internal but also foreign markets.

Nowadays the e- commerce is considered just a bone in the vast range of business known as e-business which has contributed to increase the speed of the cycles of orders and the ease of the consumers' products purchase process. Today, we can claim that the e-business is divided into four categories, as demonstrated in Figure1. This article concentrates its focus on the second superior quadrant, in short the $\mathrm{B} 2 \mathrm{C}$.

\subsection{Quality of Service}

The highlighting of concept is a crucial element to the reaching of operations' strategical objectives [5]. The conception of service lies on the operation mission system, in other words, the definition in which the operation systems must reach excellence [5]. The main characteristics of the service operations are the intangibility of services, the necessity of the clients' presence or a possession of his property, the fact in general that the services are produced and consumed simultaneously. [5]

Parasuraman, Zeithaml and Berry propose ten dimensions to quality in services [6] which are summarized in Table 1.

Table 1. Dimensions of Quality of Parasuraman, Zeithaml and Berry

\begin{tabular}{ll}
\hline \multicolumn{1}{c}{ Dimension } & \multicolumn{1}{c}{ Aspects } \\
\hline Reliability & Consistence of service and service reliability. \\
Sensitiveness & Promptness of employees to costumer service. \\
Competence & Required abilities to fulfill services. \\
Access & Ease of approach and contact. \\
Courtesy & Politeness, respect from the people in charge of contact. \\
Communication & Keeping clients informed by using language they are able to \\
& understand. \\
Credibility & It means being trusty and honest. \\
Security & It means being rid of danger, risk or doubt. \\
Comprehension & It has to do with the efforts to attend clients'neccessities. \\
Tangibles & Physical facilities, personnel appearance, equipment. \\
\hline
\end{tabular}

Rotondaro and Carvalho also present a relation of dimensions to evaluate the quality of a certain service, based upon Parasuraman, Zeithaml and Berry [7]. These dimensions include not only the ones presented by Parasuraman, Zeithaml and Berry, but also the dimensions presented in Table 2. 
Table 2. Dimensions of Quality of Rotondaro and Carvalho

\begin{tabular}{ll}
\hline Dimension & \multicolumn{1}{c}{ Aspects } \\
\hline Costumer Service & Level of employees attention in contact with consumers. \\
Resposiveness & Willingness to help and provide fast services to customers. \\
Competence & $\begin{array}{l}\text { Having the required ability and knowlege to accomplish provided } \\
\text { services. } \\
\text { Degree of lack of variability between specification and provided } \\
\text { service. }\end{array}$ \\
Consistency & $\begin{array}{l}\text { Proximity and availability at any time from delivered benefits by } \\
\text { services. } \\
\text { Convenience }\end{array}$ \\
Speed to commence and accomplish costumer service. \\
Flexibility
\end{tabular}

These dimensions are used as basis for a model creation to evaluate the quality of services of B2C enterprises.

\section{Methodology}

Two questionnaires have been elaborated for the research, base on the Table 3, created by an adaptation of Parasuranaman, Zeithaml and Barry [6], Rotondaro and Carvalho [7]. At first a questionnaire with open directed questions was sent to companies, having as a goal knowing their proceedures towards sales services, distribution and post-sale from commercialized products through sites.

In a secondary moment, the research was characterized by the data obtained from consumers, in comparison with the data obtained in the companies so that we could have an evaluation from the Quality services. The users of the Brazilian B2C replied to adapted questionnaires through "closed questions". Although the analyses of the obtained data must be done through quality manners [8]. In the present work we understand this qualification as reference to quality responses obtained through the analyses of obtained responses. This accordingly to the conception of FORZA, which claims the obtaining of individuals information or from their environment through questionnaires, interviews or other sources being exploratory, explanatory, interviews or discriptive [9].

Thus, 120 consumers have been interviewed without personal identification neccessity from purchase sites. This is explained, once in these markets clients tend to buy from various sites, accordingly to sales conditions, reliability, credibility, among other characteristics. The answers highlight five categories [10], being A (very important), B (important), C (average importance), D (fair importance) and E (irrelevant). 
Table 3. Dimensions of Quality Evaluation

\begin{tabular}{ll}
\hline \multicolumn{1}{c}{ Dimensions } & \multicolumn{1}{c}{ Aspects } \\
\hline Reliabiliy & The enterprise capacity to accomplish what has been promised. \\
Sensitiveness of Service & $\begin{array}{l}\text { Employees capacity to attend and solve the entry sites } \\
\text { consumers problems and solve doubts quickly. }\end{array}$ \\
Competence & Contact employees ability with entry site consumers. \\
Acess & $\begin{array}{l}\text { Entry sites consumers ease to get services through telephoning. } \\
\text { Courtesy }\end{array}$ \\
Presserving clients products and being kind in the delivery. \\
Communicating clearly all relevant pieces of information to \\
clients especially concerning purchasing, delivery and payment \\
conditions. \\
Companies credibility towards entry sites consumers. \\
Cecurity & $\begin{array}{l}\text { Security to the client ensuring his personal data are going to be } \\
\text { preserved and also that they will not have problems concerning } \\
\text { the purchase or payment. } \\
\text { The capacity the company has to understand and award most } \\
\text { frequent consumers. } \\
\text { Delivery, such as vehicle and personnel appearance, } \\
\text { expectations, besides the operational aspects of their entry sites } \\
\text { navigation. } \\
\text { Time of order accompliment. } \\
\text { The capacity of allowing the client to cancel, change, return and } \\
\text { change address as well after the order accomplishment. }\end{array}$ \\
\hline
\end{tabular}

\section{Survey}

\subsection{Companies}

For this survey 5 companies from the Brazilian B2C have been studied, they are now described, these answers from the applied questionnaires have enabled the demonstrated analysis in the item 5. The surveyed companies are described as mentioned below.

Enterprise 1. The first company is a subsidiary of a big department store, which has commenced its operations in the traditional retail market and later has adhered to ecommerce creating an exclusive brand in reference to its physical store, with the grownth of its business it was joined by the merge of other brands in the mentioned subsidiary. The company provides 700.00 items distributed in 30 different categories, it consists of six different stores, being 3 of varied items, such as electronics, telephonic, auto products, among others, a store that sells tickets to events, another for the selling of traveling packages and a financing one. 
Enterprise 2. The second enterprise is one of the pioneers, has worked since its foundation in 1948 in the retail of food. Nowadays, the group has got 340 stores making about US\$ 2,7 billions a year. It has began its operations in the eletronics business in 1995 with the launching in CD-ROM, becoming the first virtual supermarket in Brazil. Later, the group created an entry site which started having not only food products but also non- food products. In 2002 it used to offer eletronics and home appliances, besides food products. After a 30 million - dollar investment, the entry site was among the 20th most profitable companies in the group.

Enterprise 3. The third surveyed enterprise was an airline though not being a specific enterprise from the $\mathrm{B} 2 \mathrm{C}$, it sells its tickets through the web, having this way a clientcompany relationship, thus being part of the B2C. Lately it has become the third biggest airline in Brazil.

Enterprise 4. The fourth company is one of the oldest editors in Brazil, founded in 1944, it has published over 300 titles in Accounting, Economy, Business Administration, Law, Human science, Quantitive methods and Informatics located in São Paulo, it has created an entry site for the selling of its products.

Enterprise 5. The last surveyed company is the biggest producer of CD medias in Brazil, besides producing CDs and DVDs for the main music studious and record companies. Founded in 1988, for the manufacture of video-tapes, since 2005 is on the internet selling CDs and DVDs, it has gradualy increased its products portifolio in its entry site.

\subsection{Customers}

The final survey among clients in the B2C has been made through a non probabilistic sample, but believed as reasonably representative of the surveyed population. This has happened due to inaccessibility to all target population object- just a parto $f$ the population is accessible, which is called demonstrated population [11]. This sample has been take adrift among accessible people to the researcher.

The users have been questioned about the importance degree of various items from each of the mentioned aspects, the aim was to get users used to about what each of these quality aspects was about.

Aiming at getting consolided results and allow a classification, the intervieees were required to stablish from the dimensions of quality, the 3 main in the order of their preferences. Once the users have answered 36 questions. Through the application of a moderate media related to how many times each item was mentioned in first, second or third position, being applied respectively 4, 2 and 1 measures, we can then stablish the winner factors related to the quality of services B2C, shown on Table 4.

Table 4. Dimensions of Quality Responsible for Order Winner

\begin{tabular}{ll}
\hline Priority & Dimension \\
\hline 1st & Realibility \\
2nd & Security \\
3rd & Credibility \\
4th & Speed \\
5th & Communication \\
\hline
\end{tabular}




\section{Analysis of Results}

The B2C enterprises understand that their service reliability is crucial for their businesses and they try to optimize their services more and more. However, they tend to have little influence in the outbound logistics, outsourcing operations and trusting these outsourcing companies services, which are number one responsible in services dissatisfaction in consumers point of view.

We should notice that reliability is the main winner factor of orders after determining the price. The biggest problem of reliability delegation of outsourcing operators towards order delivery is that the bad logistics service can lead them into future order losses.

In relation to the service sensitiveness, there is no standard, varying accordingly to their activities and entry site structure in providing the service. As the sensitiveness of services, the access does not have a defined standard either, presenting great variation in the surveyed enterprises. Although, both have little impact in the winning of orders accordingly to the surveyed clients answers.

Regarding competence, these enterprises believe to be able to attend completely these requirements, which can bring about subjective self confidence, though this does not present great impact in the final consumer. Enterprises point courtesy towards their consumers necessary, though they do not control this aspect effectively in relation to the delivery carrier.

Enterprises expose information clearly on their sites, presenting their exchanging policy, price, and their products technical data, which are considered pretty relevant to their customers, who have determined communication as the fifth order winner factor. The company credibility is essential in enterprises and consumers point of view.

Consumers understand security as a key point in the process of purchasing products through e-commerce. Thus companies have been invested in security services to avoid frauds and preserve their clients personal data.

The enterprises understand their equipment and delivery services are suitable to the B2C service, despite clients are more and more demanding, look for short time delivery services, keeping prices acceptable.

Regarding flexibility, we have notice that some restrictions still exist in the segment once orders have already been accomplished-though this has not been an impacting factor such as speed, which leads to order winning.

\section{Conclusions}

Basing on the quality of services, we have established the quality of services in the ecommerce accordingly to Parasuraman, Zeithaml and Berry [6], Rotondaro and Carvalho [7]. Having twelve applicable quality dimensions to the $\mathrm{B} 2 \mathrm{C}$, we have based on a qualitative and exploratory methodology to identify which of those dimensions could be considered order winners and trace a quality profile towards these features within companies.

The results have provided us with a mapping from this market, which is in visible growth, allowing the participating enterprises to concentrate their efforts on the dimensions of their quality services which really can take them to order winning. 
We do not expect this work to be conclusive about this subject, because this survey may be and will be amplified towards competitiveness and ownership, so that it can catch up with the constant changing in this segment.

Finally, the survey has aimed to explore a so far just little explored and studied segment in Production Engineering, which involves the relationship consumers versus retail service producers in the e-commerce, thus expecting to have some useful contribution to the ones interested in this subject.

\section{References}

1. Pires, S.R.I.: Gestão da Cadeia de Suprimentos: Conceitos, Estratégias, Práticas e Casos. Atlas, São Paulo (2009)

2. Handfield, R.B., Nichols, E.L.: Introduction to Supply Chain Management-Business. Prentice Hall, Upper Saddle River (1999)

3. Laudon, K.C., Laudon, J.P.: Management Information Systems: Managing the Digital Firm. Prentice Hall, Upper Saddle River (2007)

4. Slack, N., Chambers, S., Johnston, R.: Operations Management. Prentice Hall, Upper Saddle River (2007)

5. Gianese, I.G.N., Corrêa, H.L.: Administração Estratégica de Serviços. Atlas, São Paulo (1994)

6. Parasuraman, A., Zeithaml, V.A., Berry, L.L.: Delivering Service Quality: Balancing Customers Perceptions and Expectations. Free Press, New York (1990)

7. Rotondaro, R.G., Carvalho, M.M.: Qualidade em Serviços. In: Carvalho, M.M., Paladini, E.P. (eds.) Gestão da Qualidade: Teoria e Casos, pp. 331-355. Campus, São Paulo (2005)

8. Gil, A.C.: Como Elaborar Projetos de Pesquisa, 4th edn., Atlas, São Paulo (2002)

9. Forza, C.: Survey Research in Operations Management: Process Based Perspective. International Journal of Operations \& Production Management 2, 152-194 (2002)

10. Alves-Mazzotti, A.J., Gwandsznajder, F.O.: Método das Ciências Naturais e Sociais: Pesquisa Quantitativa e Qualitativa. Pioneira, São Paulo (1999)

11. Costa Neto, P.L.O.: Estatística. Blucher, São Paulo (2002) 